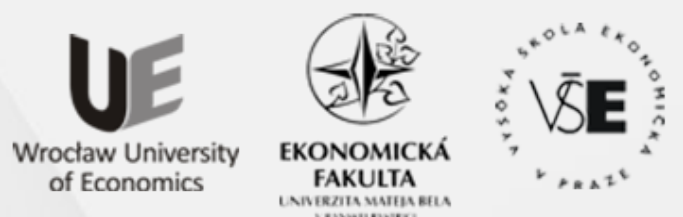

Conference Proceedings

Full TeXT PAPERS

edited by

Zofia Rusnak and Beata Zmyślona

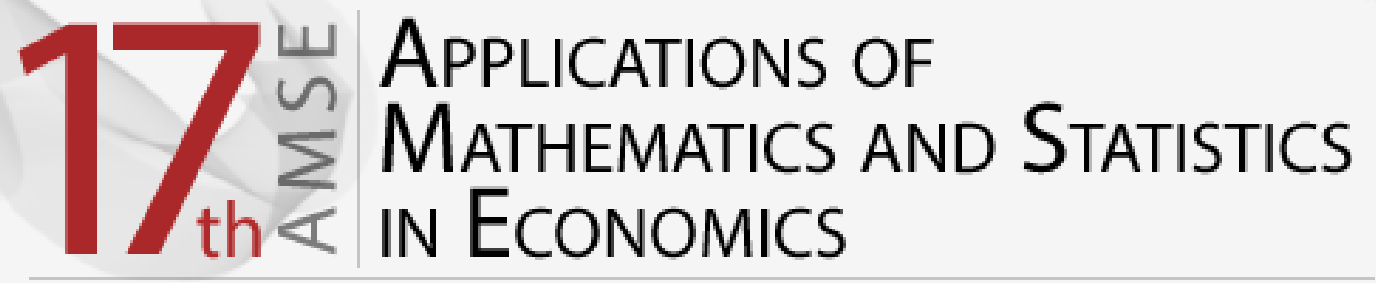

International Scientific Conference | Poland • 27-31 August 2014 
Scientific Committee

Richard Hindls, Stanislava Hronová, Rudolf Zimka, Walenty Ostasiewicz, Emília Zimková, Zofia Rusnak, Martin Bod'a

Organizing Committee

Beata Zmyślona, Cyprian Kozyra, Grzegorz Rogoziński, Kristýna Vltavská

\section{Reviewers}

Milan Bašta, Diana Bílková, Martin Bod'a, Joanna Dębicka, Tomáš Fiala, Jakub Fischer, Stanisław Heilpern, Karel Helman, Lenka Hudrlíková, Miroslav Hužvár, Nikola Kaspř́ková, Alena Kaščáková, Kamil Kladívko, Jindřich Klůfa, Pavol Král', Katarzyna Kuziak, Jana Langhamrová, Ivana Malá, Tomáš Marcinko, Luboš Marek, Miloš Maryška, Petr Mazouch, Zofia Mielecka-Kubień, Witold Miszczak, Petr Musil, Gabriela Nedelová, Walenty Ostasiewicz, Iva Pecáková, Viera Roháčová, Zofia Rusnak, Mária Stachová, Jana Špirková, Šárka Šustová, Jana Tepperová, Vladimír Úradníček, Kristýna Vltavská, Michal Vrabec, Dariusz Wawrzyniak, Henryk Zawadzki, Jaroslav Zbranek, Tomáš Zeithamer, Martin Zelený, Jan Zeman, Rudolf Zimka, Emília Zimková, Pavel Zimmermann, David Žižka

Layout

Martin Bod'a, Beata Zmyślona, Grzegorz Rogoziński

Front page design

Grzegorz Rogoziński

CD cover design

Beata Dębska

Articles published in the form submitted by the authors

All rights reserved. No part of this book may be reproduced in any form or in any means without the prior permission in writing of the Publisher

(C) Copyright by Wrocław University of Economics Wrocław 2014

ISBN 978-83-7695-421-9

Wydawnictwo Uniwersytetu Ekonomicznego we Wrocławiu

53-345 Wrocław, ul. Komandorska 118/120 www.ue.wroc.pl

Sprzedaż książek tel./fax 71 36-80-602

e-mail: econbook@ue.wroc.pl www.ksiegarnia.ue.wroc.pl 


\section{Contents}

Foreword

Diana Bílková: TL-Moments: Analogy of Classical L-Moments

Dagmar Blatná: Application of Robust Regression in the Analysis of Internet Access in European Countries

Martin Bod’a, Mária Kanderová: Rebalancing Issues in Tracking Error Variance Minimization

Martin Bod'a, Viera Roháčová: Application of Six Sigma Ideas to Timing Decisions at Financial Markets

Anton Dekrét, Rudolf Zimka: On the Price Hartwick's Task and Its Inverse in a Dynamic Model of an Economy with Exhaustible Resources

Joanna Dębicka, Agnieszka Marciniuk: Comparison of Reverse Annuity Contract and Reverse Mortgage on the Polish Market.

Petra Dotlačilová, Jitka Langhamrová: The Influence of Mortality Models for the Expected Future Life-time of Older People

Marek Ďurica, Lucia Švábová: Delta and Gamma for Chooser Options.

Vlastimil Farkašovský: New Concept of Pension Funds Performance Evaluation

Albert Gardon: The Normality of Weekly Relative Changes of the Freight Rate in Container Shipping.

Mária Grausová, Miroslav Hužvár, Jana Štrangfeldová: Healthcare Systems Efficiency in the Visegrád Group.

Stanisław Heilpern: Multiple Life Insurance - Pension Calculation

Alena Kaščáková, Gabriela Nedelová: Changes in Slovak Households' Economy

Igor Kollár, Pavol Král', Peter Laco: Methodology for Assessing Website Improvement in Corporate Environment.

Maciej Kostrzewski: Some Method of Detecting the Jump Clustering Phenomenon in Financial Time Series.

Cyprian Kozyra, Beata Zmyślona, Katarzyna Madziarska: Complementary Objective and Subjective Measures of Hospital Services Quality...

Pavol Král', Mária Stachová, Lukáš Sobíšek: Utilization of Repeatedly Measured Financial Ratios in Corporate Financial Distress Prediction in Slovakia

Ivana Malá: The Use of Finite Mixture Model for Describing Differences in Unemployment Duration

Lukáš Malec: Studying Economics and Tourism Industry Relations by Smooth Partial Least Squares Method Depending on Parameter. 
Tomáš Marcinko: Consequences of Assumption Violations Regarding Classical Location Tests.

Edyta Mazurek: The Income Tax Progression Depending on Social Insurance Contribution in Poland.

Petr Musil, Jana Kramulová, Jan Zeman: Regional Consumption Expenditures: An Important Starting Point for Regional Input-output Tables.

Katarzyna Ostasiewicz, Walenty Ostasiewicz: Good Life: From Political to Human Economy

Anna Sączewska-Piotrowska: Analysis of Poverty Transitions in Poland Using Multilevel Discrete-Time Event History Models

Martina Šimková, Petra Švarcová: Disadvantaged University Students in the Czech Republic.

Michal Široký: The Use of Short-term Business Statistics for Quarterly GDP Flash Estimates in the Czech Republic

Zdeněk Šulc, Hana Řezanková: Evaluation of Recent Similarity Measures for Categorical Data.

Lucia Švábová, Marek Ďurica: The Relationship Between the Finite Difference Method and Trinomial Trees

Kristýna Vltavská, Jaroslav Sixta: The Estimation of Final Consumption Expenditures

Lenka Vraná: Business Cycle Analysis: Tracking Turning Points

Janusz Wywiał: On Bayesian Testing in Auditing

Emília Zimková: Window Analysis of Supper-efficiency Change: Case of the Slovak Banking System ....

Beata Zmyślona: Statistical Modelling of the Impact of Diabetes on the Risk of Hospitalization 


\title{
HEALTHCARE SYSTEMS EFFICIENCY IN THE VISEGRÁD GROUP
}

\author{
MÁRIA GRAUSOVÁ \\ Matej Bel University in Banská Bystrica, Faculty of Economics, Department of Quantitative \\ Methods and Information Systems, Tajovského 10, 97590 Banská Bystrica \\ email: maria.grausova@umb.sk

\section{MIROSLAV HUŽVÁR} \\ Matej Bel University in Banská Bystrica, Faculty of Economics, Department of Quantitative \\ Methods and Information Systems, Tajovského 10, 97590 Banská Bystrica \\ email: miroslav.huzvar@umb.sk
}

\section{JANA ŠTRANGFELDOVÁ \\ Matej Bel University in Banská Bystrica, Faculty of Economics, Department of Public Economics and Regional Development, Tajovského 10,975 90 Banská Bystrica email: jana.strangfeldova@umb.sk}

\begin{abstract}
We examine healthcare systems efficiency in four countries of the Visegrád group during the period 2004-2010. For this purpose, we apply the Data Envelopment Analysis on data of 18 European countries. The number of practising physicians per 100000 inhabitants, the number of hospital beds per 100000 inhabitants and the share of health expenditures to GDP are considered as inputs, and infant mortality and life expectancy for males at birth are considered as outputs. We calculate Super-SBM efficiency scores to rank countries and to suggest improvements for the Visegrád group. To measure efficiency changes over specified time period, Malmquist productivity indexes are computed from DEA scores. Standard decomposition of Malmquist index into frontier shift and catching up effect gives a deeper insight into the issue.
\end{abstract}

Key words: Healthcare system efficiency, DEA, Super-SBM, Malmquist productivity index, Visegrád group.

DOI: $10.15611 /$ amse.2014.17.11

\section{Introduction}

The efficiency of healthcare system can be viewed from social, medical and economic points. Social efficiency pursues the fundamental objective of the development of people as individuals and the development of society as a whole. We evaluate the medical efficiency by improving the health status of the patient after consumption of adequate health services, but it is not possible to quantify this efficiency with economic indicators. Economic efficiency can be evaluated through the development of labor productivity, gross domestic product, or reproduction of human potential through the improvement of the population health.

Peacock, Chan, Mangolini, Johansen (2001) distinguish allocative and technical efficiency in relation to the better use of healthcare resources. Technical efficiency focuses on minimizing inputs to achieve an expected performance. Allocative efficiency is aimed at improving the performance indicators in health care. 
Benčo, Šebo and Štrangfeldová (2011) distinguish technical, allocative and cost efficiency. Technical efficiency targets on minimizing the volume of inputs or on maximizing the volume of outputs. Cost efficiency is based on technical efficiency, but it takes into account the relative costs of different inputs and requires minimizing the cost of inputs. Allocative efficiency connects technical and cost effectiveness with producing outputs for which there is the highest demand. Efficient allocation of resources meets all three requirements. Technical and cost efficiency draw attention to the production. Allocative efficiency focuses on the consumption, which brings together supply and demand.

Economic efficiency in health care is a combination of allocative and technical efficiency of the use of available resources. In a recent study of OECD countries it was found that the efficiency of Slovak healthcare system is at $61.2 \%$. It follows that from every euro in the system we lose 39 cents, which are not used to improve population health (Bezekova, 2007).

Many researchers have focused attention on the measurement of efficiency in the healthcare. Hollingsworth (2008) reviewed 317 references on frontier efficiency in the context of health services delivery. But just a few studies have recently implemented the efficiency measurement techniques under a macro level perspective, i.e. evaluating the overall healthcare system's performance. Different approaches were found regarding the inputs and outputs incorporated into the models. Authors used to examine the impact of socioeconomic determinants, the social environment, population lifestyles, attitudes and behaviors, available medical care services, and health expenditure on healthcare outcomes. In most of these studies, the healthcare outcome was measured by life expectancy at birth, while expenditure on health per capita was included as one of the inputs. Only few studies (Bhat, 2005, Afonso et al., 2005) included the number of inpatient beds and levels of health employment as inputs rather than health expenditure.

According to Hadad et al. (2013), various Data Envelopment Analysis (DEA) approaches have been widely developed and applied in the evaluation of the health services performance.

Our study focuses on the development of the healthcare systems efficiency in the countries of the Visegrád group during the period 2004-2010. In order to observe relative efficiencies, we apply DEA on data of 18 European countries. Firstly we calculate the super-efficiency scores to compare and rank the healthcare systems of the countries of the Visegrád group within Europe. Secondly, we analyze their healthcare system efficiency development using Malmquist productivity index and its decomposition into frontier shift and catch up effect. The results of the analysis contribute to the deeper understanding of the healthcare systems efficiency and the success of national healthcare policies of the Visegrád countries.

\section{Methodology}

We apply DEA to measure technical efficiency of healthcare systems in Visegrád group regarding to 18 European countries. This approach allows us to deal with several indicators of different nature as the inputs and outputs of the healthcare systems.

\subsection{DEA model}

We utilize a non-radial and non-oriented DEA model. A non-oriented model is appropriate in our context, since healthcare system desires both to maximize health gains and minimize inputs. Generally, DEA model allows us to determine efficient and inefficient systems. Efficient systems are assigned the unit efficiency scores, while inefficient systems are 
assigned efficiency scores less than one. In order to distinguish the efficient healthcare systems, we apply so-called super-efficiency. The super-efficiency method for radial models was developed by Andersen and Petersen (1993) to rank the efficient decision-making units (DMUs). This approach allows these DMUs to receive an efficiency score greater than one. Tone (2002) introduced non-radial super-efficiency models using the slack-based model (SBM).

\subsection{Malmquist index}

The Malmquist index (MI) evaluates the efficiency change of a DMU between two time periods. It differs from other index numbers in its ability to distinguish between improved possibilities of performance (e.g., due to technological change) and the degree to which each of the evaluated entities has taken advantage of these possibilities, in both periods. It is an index representing Total Factor Productivity (TFP) of the DMU, in that it reflects progress or regress in efficiency of the DMU along with progress or regress of the frontier technology. It is defined as the product of "Catch-up" and "Frontier-shift" terms.

The catch-up term is related to the degree of efforts that the DMU attained for improving its efficiency, while the frontier-shift term reflects the change in the efficient frontiers surrounding the DMU between the two time periods 1 and 2 .

In a non-parametric framework the Malmquist index (MI) is constructed by means of DEA technologies. There are a number of ways to compute MI. We computed MI from the nonradial and non-oriented SBM model.

\section{Data and variables}

In the present study, we measure the efficiency of healthcare systems in four countries of the Visegrád group during the period 2004-2010 in relation to other European countries. DEA analysis requires that the number of DMUs should be at least three times greater than the total number of inputs and outputs used in the computation. Therefore we include to our comparison 18 countries for which the data is available during the period, i.e. Austria, Belgium, Cyprus, Czech Republic, Estonia, Finland, Germany, Hungary, Latvia, Lithuania, Luxembourg, Norway, Poland, Romania, Slovakia, Slovenia, Spain and Sweden. These countries are considered to be DMUs for DEA.

Data has been collected from two sources: the Eurostat Statistics Database [9] and the OECD Health Data [10]. Two outputs were chosen - life expectancy at birth of males and infant mortality rate (transformed to correspond with the DEA assumptions as follows). The DEA technique implies that outputs are measured in such a way that "more is better". Since infant mortality rate (IMR) does not meet this rationale, we calculate the modified infant mortality rate (MIMR) by the formula MIMR $=1000 / \mathrm{IMR}$. The inputs included in our analysis are the number of practising physicians per 100000 inhabitants, the number of hospital beds per 100000 inhabitants and the share of public health expenditures in relation to GDP. Since data on practising physicians in Slovakia and Finland is not available for some of observed years, we estimate the missing values based on the number of professionally active physicians [9]. Input and output data definitions and sources are presented in Table 1. 
Table 1. Definition and source of variables included in the DEA models.

\begin{tabular}{|c|c|c|c|}
\hline Variable & Role & Definition & Data source \\
\hline $\begin{array}{l}\text { Practising } \\
\text { physicians }\end{array}$ & Input & $\begin{array}{l}\text { The total number of practising } \\
\text { physicians (medical doctors) in a given } \\
\text { calendar year, per } 100,000 \text { inhabitants. } \\
\text { Practising physicians provide services } \\
\text { directly to patients. }\end{array}$ & [9] \\
\hline Hospital beds & Input & $\begin{array}{l}\text { The total number of hospital beds in a } \\
\text { given calendar year, per 100,000 } \\
\text { inhabitants. }\end{array}$ & [9] \\
\hline Share of GDP & Input & $\begin{array}{l}\text { Share of public health expenditures in } \\
\text { relation to GDP. }\end{array}$ & {$[10]$} \\
\hline $\begin{array}{l}\text { Modified } \\
\text { mortality }\end{array}$ & $\begin{array}{l}\text { Output } \\
\text { (transformed) }\end{array}$ & $\begin{array}{l}1000 \text { live births over the number of } \\
\text { deaths of infants under } 1 \text { month of age. }\end{array}$ & [9] \\
\hline Life expectancy & Output & $\begin{array}{l}\text { Life expectancy in absolute value at } \\
\text { birth - males. }\end{array}$ & [9] \\
\hline
\end{tabular}

Source: Author's work.

The data is analyzed using DEA-Solver software (version 7.0, www.saitech-inc.com).

Table 2 shows the development of selected input and performance indicators for Visegrád (V4) countries over 7 years (2004-2010) as well as descriptive statistics for 18 countries in comparison.

The Czech Republic reports the highest number of practising physicians throughout the period with a continued moderate increase. Poland has the lowest number of practising physicians with a declining trend.

Hungary leads in hospital beds and in spite of the significant decrease in the year 2007 still has the highest number of hospital beds among the V4 countries. Poland shows the lowest number of hospital beds at the beginning of the period, but in the last three years Slovak Republic has the lowest values of this indicator.

The share of financial resources directed to the health sector in gross domestic product in the V4 countries varies from $4.0 \%$ in Poland up to $6.4 \%$ in the Czech Republic. The share in individual countries is increasing except Hungary, where the share in 2007 fell down from $5.5 \%$ to $5.0 \%$ and remains at this level till the end of the period. In 2007 we observe a similar decrease of the share in the Czech Republic, but in the following years the share gradually increases and reaches the previous level.

As performance indicators we take child mortality and average life expectancy of males at birth in absolute values.

We modified the indicator of child mortality so as to maximize its value (to be a desired output of the DEA method used). We see that the most unfavorable situation in child mortality is in the Slovak Republic and in Hungary. The best outcomes of this indicator are in the Czech Republic.

The average life expectancy of men at birth increases in all V4 countries. Men in the Czech Republic and in Hungary are expected to live to the highest and lowest age, respectively. 


\section{Am Amanconos of Mathematics and Statistics IN ECONOMICS}

International Scientific Conference | Poland • 27-31 August 2014

Table 2. Data and descriptive statistics.

\begin{tabular}{|c|c|c|c|c|c|c|c|c|}
\hline Indicator & geoltime & 2004 & 2005 & 2006 & 2007 & 2008 & 2009 & 2010 \\
\hline \multirow{8}{*}{$\begin{array}{l}\text { Practising } \\
\text { physicians }\end{array}$} & Czech Republic & 352 & 355 & 356 & 356 & 354 & 356 & 359 \\
\hline & Hungary & 334 & 278 & 304 & 280 & 309 & 302 & 287 \\
\hline & Poland & 229 & 214 & 218 & 219 & 216 & 217 & 217 \\
\hline & Slovakia & 315 & 289 & 301 & 300 & 320 & 313 & 319 \\
\hline & Mean - V4 & 307 & 284 & 295 & 289 & 300 & 297 & 295 \\
\hline & Mean - 18 countries & 304 & 305 & 309 & 313 & 318 & 319 & 324 \\
\hline & Minimum - 18 countries & 208 & 214 & 216 & 212 & 216 & 217 & 217 \\
\hline & Maximum - 18 countries & 420 & 432 & 445 & 454 & 460 & 468 & 478 \\
\hline \multirow{8}{*}{$\begin{array}{l}\text { Hospital } \\
\text { beds }\end{array}$} & Czech Republic & 764 & 755 & 743 & 731 & 719 & 711 & 703 \\
\hline & Hungary & 783 & 785 & 792 & 719 & 711 & 714 & 718 \\
\hline & Poland & 667 & 652 & 647 & 642 & 662 & 665 & 656 \\
\hline & Slovakia & 690 & 677 & 671 & 675 & 656 & 651 & 644 \\
\hline & Mean - V4 & 726 & 717 & 713 & 692 & 687 & 685 & 680 \\
\hline & Mean - 18 countries & 631 & 617 & 607 & 597 & 592 & 580 & 567 \\
\hline & Minimum - 18 countries & 301 & 293 & 289 & 286 & 281 & 276 & 273 \\
\hline & Maximum - 18 countries & 858 & 847 & 830 & 824 & 821 & 824 & 825 \\
\hline \multirow{8}{*}{$\begin{array}{l}\text { Share of } \\
\text { GDP }\end{array}$} & Czech Republic & 5,9 & 5,8 & 5,6 & 5,3 & 5,5 & 6,4 & 6,0 \\
\hline & Hungary & 5,5 & 5,7 & 5,5 & 5,0 & 4,9 & 5,0 & 5,0 \\
\hline & Poland & 4,0 & 4,0 & 4,1 & 4,2 & 4,6 & 4,8 & 4,7 \\
\hline & Slovakia & 5,1 & 5,1 & 4,9 & 5,1 & 5,4 & 6,0 & 5,8 \\
\hline & Mean - V4 & 5,1 & 5,2 & 5,0 & 4,9 & 5,1 & 5,6 & 5,4 \\
\hline & Mean - 18 countries & 6,1 & 5,5 & 5,5 & 5,6 & 5,8 & 6,3 & 6,4 \\
\hline & Minimum - 18 countries & 3,8 & 2,5 & 2,8 & 3,4 & 3,3 & 3,0 & 4,1 \\
\hline & Maximum - 18 countries & 7,9 & 8,0 & 7,9 & 7,8 & 7,9 & 8,7 & 8,6 \\
\hline \multirow{8}{*}{$\begin{array}{l}\text { Modified } \\
\text { mortality }\end{array}$} & Czech Republic & 270 & 294 & 303 & 323 & 357 & 345 & 370 \\
\hline & Hungary & 152 & 161 & 175 & 169 & 179 & 196 & 189 \\
\hline & Poland & 147 & 156 & 167 & 167 & 179 & 179 & 200 \\
\hline & Slovakia & 147 & 139 & 152 & 164 & 169 & 175 & 175 \\
\hline & Mean - V4 & 179 & 188 & 199 & 206 & 221 & 224 & 234 \\
\hline & Mean - 18 countries & 216 & 235 & 249 & 263 & 280 & 275 & 281 \\
\hline & Minimum - 18 countries & 60 & 67 & 72 & 83 & 91 & 99 & 102 \\
\hline & Maximum - 18 countries & 323 & 417 & 400 & 556 & 556 & 417 & 435 \\
\hline \multirow{8}{*}{$\begin{array}{l}\text { Life } \\
\text { expectancy }\end{array}$} & Czech Republic & 72,5 & 72,9 & 73,5 & 73,8 & 74,1 & 74,3 & 74,5 \\
\hline & Hungary & 68,7 & 68,7 & 69,2 & 69,4 & 70,0 & 70,3 & 70,7 \\
\hline & Poland & 70,6 & 70,8 & 70,9 & 71,0 & 71,3 & 71,5 & 72,1 \\
\hline & Slovakia & 70,3 & 70,2 & 70,4 & 70,6 & 70,9 & 71,4 & 71,8 \\
\hline & Mean - V4 & 70,5 & 70,7 & 71,0 & 71,2 & 71,6 & 71,9 & 72,3 \\
\hline & Mean - 18 countries & 72,9 & 73,0 & 73,5 & 73,6 & 74,1 & 74,5 & 74,9 \\
\hline & Minimum - 18 countries & 65,6 & 64,9 & 65,0 & 64,5 & 65,9 & 67,1 & 67,6 \\
\hline & Maximum - 18 countries & 78,4 & 78,5 & 78,8 & 79,0 & 79,2 & 79,4 & 79,6 \\
\hline
\end{tabular}

Source: Author's work based on [9] and [10]. 


\section{Results and discussion}

Evaluating super-efficiency scores for reference years in the V4 countries (for details see Table. 3), we can conclude that the best placed is the health system of Poland, although in 2005-2007 experienced some fall among the surveyed countries. In 2010, however, Poland returned to the forefront walls among the evaluated countries.

Table 3. Super-efficiency scores, ranks and projections.

\begin{tabular}{|c|c|c|c|c|c|c|c|c|c|}
\hline & & & 2004 & 2005 & 2006 & 2007 & 2008 & 2009 & 2010 \\
\hline \multirow{7}{*}{$\begin{array}{l}\text { Czech } \\
\text { Republic }\end{array}$} & \multicolumn{2}{|l|}{ Scores } & 0,75 & 0,71 & 0,70 & 0,61 & 0,69 & 0,69 & 0,79 \\
\hline & \multicolumn{2}{|l|}{ Ranks } & 11 & 13 & 12 & 12 & 11 & 11 & 11 \\
\hline & \multirow{5}{*}{$\begin{array}{l}\text { Projections } \\
(\%)\end{array}$} & Practising physicians & -35 & -29 & -27 & -25 & -25 & -32 & -27 \\
\hline & & Hospital beds & -37 & -23 & -24 & -22 & -21 & -35 & -33 \\
\hline & & Share of GDP & -2 & 0 & -2 & -2 & 0 & -3 & 0 \\
\hline & & Modified mortality & 0 & 28 & 32 & 72 & 40 & 21 & 2 \\
\hline & & Life expectancy & 1 & 5 & 4 & 4 & 4 & 2 & 1 \\
\hline \multirow[t]{7}{*}{ Hungary } & \multicolumn{2}{|l|}{ Scores } & 0,58 & 0,52 & 0,50 & 0,45 & 0,54 & 0,66 & 0,74 \\
\hline & \multicolumn{2}{|l|}{ Ranks } & 16 & 17 & 18 & 16 & 14 & 13 & 12 \\
\hline & \multirow{5}{*}{$\begin{array}{l}\text { Projections } \\
(\%)\end{array}$} & Practising physicians & -31 & -9 & -14 & -7 & -18 & -22 & 0 \\
\hline & & Hospital beds & -35 & -26 & -29 & -20 & -17 & -25 & -22 \\
\hline & & Share of GDP & 0 & 0 & 0 & 0 & 0 & 0 & 0 \\
\hline & & Modified mortality & 65 & 127 & 128 & 197 & 119 & 51 & 48 \\
\hline & & Life expectancy & 6 & 11 & 11 & 9 & 7 & 5 & 1 \\
\hline \multirow[t]{7}{*}{ Poland } & \multicolumn{2}{|l|}{ Scores } & 1,08 & 1,02 & 1,01 & 1,00 & 1,02 & 1,02 & 1,13 \\
\hline & \multicolumn{2}{|l|}{ Ranks } & 3 & 9 & 8 & 8 & 6 & 5 & 3 \\
\hline & \multirow{5}{*}{$\begin{array}{l}\text { Projections } \\
(\%)\end{array}$} & Practising physicians & 0 & 6 & 3 & 1 & 5 & 6 & 10 \\
\hline & & Hospital beds & 0 & 0 & 0 & 0 & 0 & 0 & 0 \\
\hline & & Share of GDP & 25 & 0 & 0 & 0 & 0 & 0 & 28 \\
\hline & & Modified mortality & 0 & 0 & 0 & 0 & 0 & 0 & 0 \\
\hline & & Life expectancy & 0 & 0 & 0 & 0 & 0 & 0 & 0 \\
\hline \multirow[t]{7}{*}{ Slovakia } & \multicolumn{2}{|l|}{ Scores } & 0,66 & 0,55 & 0,55 & 0,42 & 0,46 & 0,50 & 0,56 \\
\hline & \multicolumn{2}{|l|}{ Ranks } & 13 & 16 & 17 & 17 & 17 & 18 & 15 \\
\hline & \multirow{5}{*}{$\begin{array}{l}\text { Projections } \\
(\%)\end{array}$} & Practising physicians & -27 & -15 & -12 & 12 & -17 & -23 & -14 \\
\hline & & Hospital beds & -20 & -11 & -16 & -15 & -13 & -27 & -25 \\
\hline & & Share of GDP & 0 & 0 & 0 & 0 & 0 & 0 & 0 \\
\hline & & Modified mortality & 51 & 122 & 128 & 223 & 185 & 126 & 107 \\
\hline & & Life expectancy & 3 & 7 & 5 & 8 & 8 & 6 & 3 \\
\hline
\end{tabular}

Source: Author's work.

Although the Czech Republic does not show high super-efficiency scores, it maintains its position among the surveyed countries with small fluctuations. Hungary together with the 


\section{$12 \backsim$ APPLICATIONS OF \\ $\sum$ Mathematics and Statistics \\ IN ECONOMICS}

International Scientific Conference | Poland • 27-31 August 2014

Slovak Republic ranged in assessing the super-effectiveness the lowest positions. In Hungary, however, the health system becomes more efficient. Despite the fact that in the early years it lags behind the Slovak Republic, in the last studied years it has significantly improved its position, while the health system in the Slovak Republic has lagged. Even in 2009, Slovakia occupied the last place among the surveyed countries.

Comparing the recommended projections for individual input and output indicators between years and among the V4 countries, we can find opportunities to be done in order to achieve efficiency of health systems. We observe that Poland has the best condition and development of the monitored indicators. Even with an increase in the number of physicians and the expenditure ratio to GDP Poland is able to maintain the efficiency of its system. The Czech Republic, according to the results should reduce the number of doctors and the number of beds and slightly reduce the share of health expenditure to GDP. To achieve efficiency in output indicators should be primarily reduced child mortality. Hungary, together with the Slovak Republic, may also further reduce the number of practising physicians and hospital beds. However, problematic in these countries are performance indicators. The child mortality and life expectancy do not correspond to the level of healthcare system inputs.

When evaluating the distance of the health systems of the V4 countries to the efficiency frontier (see Figure 1.), we can conclude that only the health system in Poland reaches the maximum efficiency during the whole period. The healthcare system of the Slovak Republic has the largest fluctuations regarding to the efficiency frontier. A positive finding is that all V4 countries are moving closer to the frontier in recent years. However, we can talk just about the so-called false improving, because the border efficiency decreases.

Czech republic

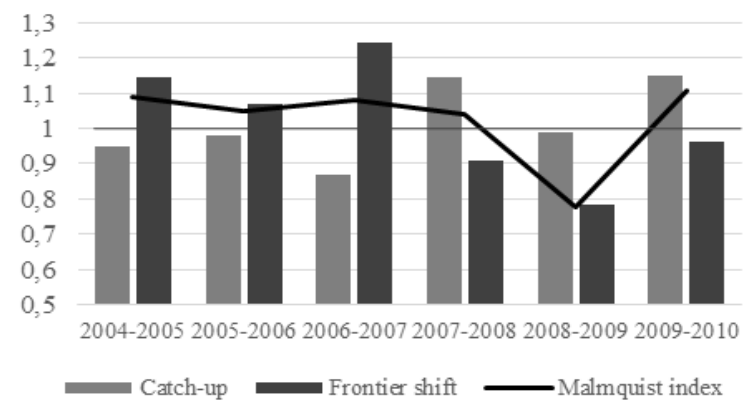

Poland

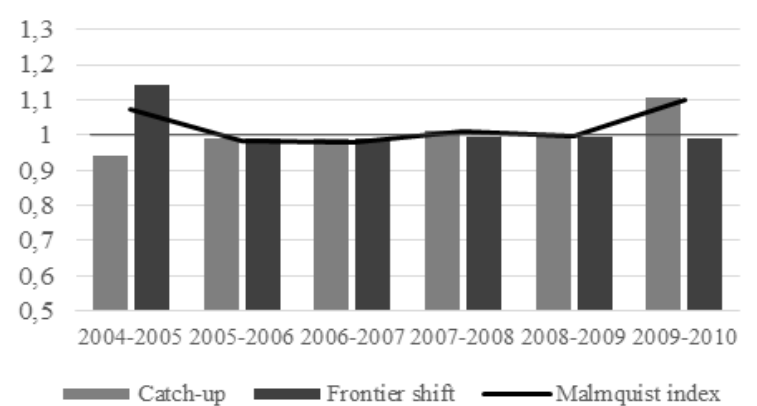

Hungary

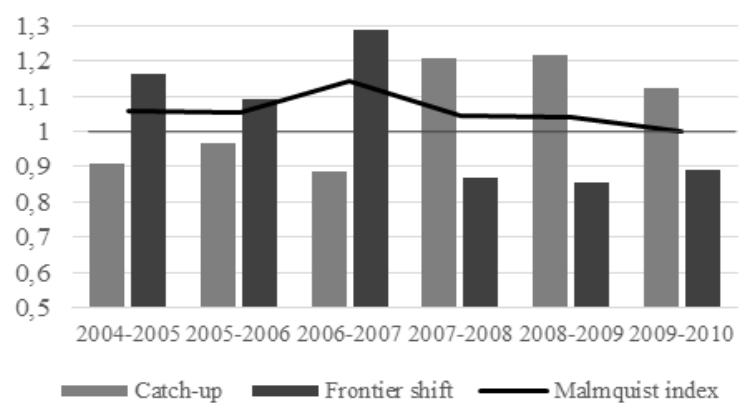

Slovakia

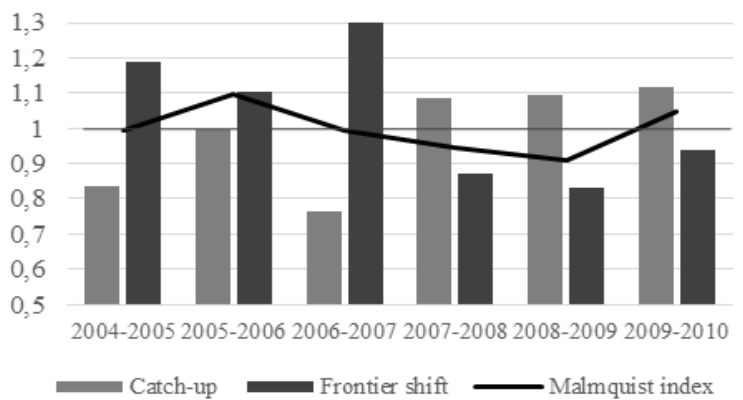

Figure 1. Development of relative healthcare efficiency in V4 countries. Source: Author's work. 
Malmquist index points to the fact that the Czech and Slovak Republic, despite the decreasing effectiveness of the frontier, still show a decrease in their effectiveness against it. It follows that the levels of health systems efficiency in these countries decreases. On the other hand, the development of health systems in Poland and Hungary is more stable.

\section{Conclusion}

We applied DEA to analyse the relative efficiency of healthcare systems in the V4 countries within the group of 18 European countries in the period 2004-2010. We found that the health system in Poland belongs to the most efficient within the compared countries although the deeper super-efficiency analysis shows some insufficiencies and fluctuations.

The other three countries have relatively inefficient health systems in all years. But their development is different. The Czech Republic keeps a stable position in the ranking. Hungary took one of the last places in the ranking in the first years, but has significantly improved its position at the end of the period. On the contrary, Slovakia remains at very low positions in the ranking for the whole period. The Malmquist index decomposition reveals that all the three countries approach to the efficiency frontier in the last three years (2008-2010). But this optimistic observation is only partially due to the improvement of their real efficiencies since the efficiency of reference countries significantly decreased between years 2007 and 2008 . The real reasons of this development will be a matter of further research.

\section{Acknowledgements}

This article is based upon work supported by the Project: Mobility - enhancing research, science and education at the Matej Bel University, ITMS code: 26110230082, under the Operational Program Education cofinanced by the European Social Fund.

\section{Appendix: the DEA methodology}

In this section, we first present the Malmquist index, and then we present the DEA models, according to Cooper et al. (2007). Let us recall, that the Malmquist index is defined as the product of "Catch-up" and "Frontier-shift" terms.

We denote the activities of $\mathrm{DMU}_{\mathrm{o}}$ at the time period 1 and 2 by $\left(x_{\mathrm{o}}, y_{\mathrm{o}}\right)^{1}$ and $\left(x_{\mathrm{o}}, y_{\mathrm{o}}\right)^{2}$, respectively. Then we develop the numerical measures for which we employ the notation $\delta^{s}\left(\left(x_{0}, y_{0}\right)^{t}\right)(t=1,2$ and $s=1,2)$, for the efficiency score of $\mathrm{DMU}_{\mathrm{o}}$ at the time period $t$ measured by the frontier technology $s$.

Using this notation, the Catch-up effect can be expressed by the following formula.

$$
\text { Catch-up }=\frac{\delta^{2}\left(\left(x_{o}, y_{o}\right)^{2}\right)}{\delta^{1}\left(\left(x_{o}, y_{o}\right)^{1}\right)}
$$

(Catch-up) $>1$ indicates progress in relative efficiency from period 1 to 2 , while (Catchup) $=1$ and $($ Catch-up $)<1$ indicate the status quo and regress in efficiency, respectively. In addition to the catch-up term, we must take account the frontier-shift effect in order to totally evaluate the efficiency change of the DMU, since the catch-up is determined by the efficiencies as measured by the distances from the respective frontiers.

The Frontier shift effect is described as 


\section{APPLICATIONS OF

$$
\text { Frontier shift }=\left[\frac{\delta^{1}\left(\left(x_{o}, y_{o}\right)^{1}\right)}{\delta^{2}\left(\left(x_{o}, y_{o}\right)^{1}\right)} \times \frac{\delta^{1}\left(\left(x_{o}, y_{o}\right)^{2}\right)}{\delta^{2}\left(\left(x_{o}, y_{o}\right)^{2}\right)}\right]^{1 / 2} .
$$

As the product of Catch-up and Frontier-shift, we obtain the following formula for the computation of MI, the Malmquist index.

$$
\mathrm{MI}=\left[\frac{\delta^{1}\left(\left(x_{o}, y_{o}\right)^{2}\right)}{\delta^{1}\left(\left(x_{o}, y_{o}\right)^{1}\right)} \times \frac{\delta^{2}\left(\left(x_{o}, y_{o}\right)^{2}\right)}{\delta^{2}\left(\left(x_{o}, y_{o}\right)^{1}\right)}\right]^{1 / 2} .
$$

This last expression gives another interpretation of MI as the geometric mean of the two efficiency ratios: the one being the efficiency change measured by the period 1 technology and the other the efficiency change measured by the period 2 technology. As can be seen from these formulas, MI consists of four terms: $\delta^{1}\left(\left(x_{0}, y_{0}\right)^{1}\right), \delta^{2}\left(\left(x_{0}, y_{0}\right)^{2}\right), \delta^{1}\left(\left(x_{0}, y_{0}\right)^{2}\right)$ and $\delta^{1}\left(\left(x_{0}\right.\right.$, $\left.\left.y_{\mathrm{o}}\right)^{2}\right)$. The first two are related to the measurements within the same time period with $t=1$ or $t$ $=2$, while the last two are for intertemporal comparison. MI $>1$ indicates progress in the total factor productivity of the $\mathrm{DMU}_{\mathrm{o}}$ from period 1 to 2 , while $\mathrm{MI}=1$ and $\mathrm{MI}<1$ respectively indicate the status quo and deterioration in the total factor productivity.

We utilized a non-radial and non-oriented model. The models in this category deal with input and output slacks. The [SBM] and [Super-SBM] models used for computing $\delta^{s}\left(\left(x_{0}, y_{\mathrm{o}}\right)^{t}\right)$ are represented by the following fractional programs:

$[\mathrm{SBM}]$

$$
\begin{aligned}
& \delta^{s}\left(\left(x_{o}, y_{o}\right)^{t}\right)=\min _{\lambda, s^{-}, s^{+}}\left(1-\frac{1}{m} \sum_{i=1}^{m} s_{i}^{-} / x_{i o}^{t}\right) /\left(1+\frac{1}{q} \sum_{i=1}^{q} s_{i}^{+} / y_{i o}^{t}\right) \\
& \text { subject to } \\
& x_{o}^{t}=X^{s} \lambda+s^{-}, \\
& y_{o}^{t}=Y^{s} \lambda-s^{+}, \\
& L \leq e \lambda \leq U, \\
& \lambda \geq 0, s^{-} \geq 0, s^{+} \geq 0 .
\end{aligned}
$$

Where $X^{s}=\left(x_{1}^{s}, \ldots, x_{n}^{s}\right)$ and $Y^{s}=\left(y_{1}^{s}, \ldots, y_{n}^{s}\right)$ are respectively input and output matrices of observed data for period $s$, the vectors $s^{+}$and $s^{-} \in R^{m}$ denotes output and input-slacks. We solve this program for $s=1$ and 2 . It holds that $\delta^{s}\left(\left(x_{0}, y_{0}\right)^{t}\right) \leq 1$, and $\delta^{s}\left(\left(x_{0}, y_{0}\right)^{s}\right)=1$ indicates $\left(x_{0}, y_{\mathrm{o}}\right)^{s}$ being on the technically efficient frontiers of $(X, Y)^{s}$.

[Super-SBM]

$$
\delta^{s}\left(\left(x_{o}, y_{o}\right)^{t}\right)=\min _{\lambda, s^{-}, s^{+}}\left(\frac{1}{m} \sum_{i=1}^{m} \bar{x}_{i} / x_{i o}^{s}\right) /\left(\frac{1}{q} \sum_{i=1}^{q} \bar{y}_{i} / y_{i o}^{s}\right)
$$

subject to 


$$
\begin{aligned}
& \bar{x} \geq X^{s} \lambda, \\
& \bar{y} \leq Y^{s} \lambda, \\
& \bar{x} \geq x_{o}^{t}, \bar{y} \leq y_{o}^{t} \\
& L \leq e \lambda \leq U, \\
& \bar{y} \geq 0, \lambda \geq 0 .
\end{aligned}
$$

We solve this program for the pairs $(s, t)=(1,2)$ and $(2,1)$. If $\left(x_{0}, y_{0}\right)^{t}$ is not enveloped by the technology of period $s$, the score $\delta^{s}\left(\left(x_{0}, y_{0}\right)^{t}\right)$, if it exists, results in a value greater than 1 .

These fractional programs can be transformed into LPs. See Tone (2002) for detailed method of doing so. This model under the exclusive scheme evaluates the four components of MI: $\delta^{1}\left(\left(x_{0}, y_{0}\right)^{1}\right), \delta^{2}\left(\left(x_{0}, y_{0}\right)^{2}\right), \delta^{1}\left(\left(x_{0}, y_{0}\right)^{2}\right)$ and $\delta^{1}\left(\left(x_{0}, y_{0}\right)^{2}\right)$ using [SBM], and, if the corresponding LP is found infeasible, we then apply [Super-SBM].

\section{References}

1. AFONSO, A., ST AUBYN, M., 2005, Non-parametric approaches to education and health efficiency in OECD countries, J. Appl. Econ. 8., 227-246.

2. ANDERSEN, P., PETERSEN, N.C., 1993, A procedure for ranking efficient units in data envelopment analysis, Management Science 39, 1261-1264.

3. BENČO, J., ŠEBO, J., ŠTRANGFELDOVÁ, J., 2011, Hodnotenie efektívnosti vo verejných službách, Ekonomika verejných služieb. Banská Bystrica: EF UMB, 2011. ISBN 978-80-557-0323-7.

4. BEZEKOVÁ, P., 2007, Reforma zdravotníctva v SR, Diploma thesis, Praha: FM VŠE, http://www.vse.cz/vskp/show_file.php?soubor_id=6949

5. BHAT, V.N., 2005, Institutional arrangements and efficiency of health care delivery systems, Eur. J. Health Econ. 6, 215-222.

6. COOPER, W.W., SEIFORD, L.M., TONE, K., 2007, Data envelopment analysis, A comprehensive text with models, applications, references and DEA-Solver Software, second ed., Springer, New York

7. HADAD, S., HADAD, Y., SIMON-TUVAL, T., 2013, Determinants of healthcare system's efficiency in OECD countries, Eur. J. Health Econ.14 (2), 253-265.

8. HOLLINGSWORTH, B., 2008, The measurement of efficiency and productivity of health care delivery, Health Econ. 17, 1107-1128.

9. http://epp.eurostat.ec.europa.eu/portal/page/portal/statistics/search_database

10. OECD, Health at a Glance 2013: OECD Indicators, OECD Publishing, http://dx.doi.org/10.1787/health_glance-2013-en

11. PEACOCK, S., CHAN, C., MANGOLINI, M. and JOHANSEN, D., 2001, Techniques for Measuring efficiency in Health Services, Productivity Commission Staff Working Paper, July. http://www.pc.gov.au/_data/assets/pdf_file/0018/60471/tmeihs

12. TONE, K., 2002. A slacks-based measure of super-efficiency in data envelopment analysis, Eur. J. Oper. Res. 143, 32-41. 